doi: 10.18484/2305-0047.2017.2.177

\author{
S.E. KATORKIN, A.V. KOLSANOV, S.A. BYSTROV, \\ S.S. CHAPLYGIN, P.M. ZELTER, R.M. NAZAROV
}

\title{
PREOPERATIVE 3D MODELING SPLENECTOMY IN PATIENTS WITH PRIMARY IMMUNE THROMBOCYTOPENIA
}

\author{
FSBEE HE «Samara State Medical University», Samara \\ The Russian Federation
}

Цель. Изучить эффективность предоперационного 3-D моделирования на основе анализа данных мультиспиральной компьютерной томографии при выполнении лапароскопической спленэктомии по поводу первичной иммунной тромбоцитопении.

Материал и методы. Пациентка, 55 лет с диагнозом идиопатическая тромбоцитопеническая пурпура, рецидивирующее течение. В течение 10 лет она наблюдалась и проходила неоднократные курсы консервативного лечения, принимала ежедневно до 60 мг преднизолона. Уровень тромбоцитов крови снижался ниже $30 \times 10^{9} /$ л. В связи с неэффективностью консервативного лечения была показана спленэктомия. Выполнена мультиспиральная компьютерная томография с болюсным контрастированием. На основе полученных данных в системе «Автоплан» была построена цветная 3-D модель области оперативного вмешательства. Система по планированию оперативного вмешательства объединяет медицинское оборудование, внутристационарную сеть архивирования и обмена данными с рабочими станциями врачей с возможностью использования на компьютерах и мобильных устройствах непосредственно в операционной. Пациентке выполнена лапароскопическая гибридная спленэктомия.

Результаты. Согласно 3-D модели, у пациентки выявлен магистральный тип васкуляризации селезенки. Дистальная часть хвоста поджелудочной железы не доходила до ворот селезенки на 1,5 см. Добавочные селезенки и перипроцесс отсутствовали. Данные модели 3-D подтвердились интраоперационно и позволили выполнить лапароскопическую гибридную спленэктомию без технических трудностей прецизионно с минимальной кровопотерей. Послеоперационный период протекал без осложнений. Пациентка выписана на 5 сутки в удовлетворительном состоянии. Показатели уровня тромбоцитов достигли референтных значений $\left(356 \times 10^{9} / л\right)$.

Заключение. Предоперационное 3-D моделирование позволяет хирургу заранее планировать оперативное вмешательство с учетом знания индивидуальных топографо-анатомических особенностей области предстоящей операции. Знание индивидуальных особенностей васкуляризации селезенки и топографии поджелудочной железы в ее воротах позволяет прецизионно выделять и легировать сосуды, что повышает качество гемостаза, а также уменьшает вероятность травмы поджелудочной железы. Дооперационная визуализация добавочных селезенок повышает радикальность операции.

Ключевые слова: спленэктомия, тромбоцитопения, компьютерная томография, 3D моделирование, гемостаз, васкуляризация

Objectives. To explore the possibilities of preoperative 3D modelling and analysis system based on multislice computed tomography data, to evaluate its effectiveness in performing laparoscopic splenectomy for the primary immune thrombocytopenia.

Methods. A female patient, (55 yrs) with the diagnosis of idiopathic thrombocytopenic purpura, recurrent course. For 10 years she had been observed and underwent the numerous courses of conservative treatment; she also took daily $60 \mathrm{mg}$ of prednisolone. The blood platelet levels reduced below $30 \times 10^{9} / 1$. The splenectomy was indicated due to the failure of conservative treatment. Multislice computed tomography with contrast bolus was performed. For preoperative planning a color 3D model of the surgical site was created on the basis of the obtained data in the "Autoplan" system. Systems giving the ability to plan surgical intervention combines the medical equipment, PACS system (picture archiving and communication system) available onsite advanced image-viewing workstations that can guide physicians; the ability to view images from various workstations via the network including the navigation enabling physicians to create the accurate and realistic models from stereo cameras, and to use computers as well as mobile computing devices directly in the operating room. The patient was underwent laparoscopic hybrid splenectomy.

Results. According to the 3D model a main type of vascularization of the spleen was revealed. The distal part of the pancreatic tail did not reach $(1.5 \mathrm{~cm})$ the gate of the spleen. Accessory spleens and periprotsess were absent. The data of 3D model were confirmed intraoperatively and allowed performing a laparoscopic hybrid splenectomy without technical difficulties precisely with a minimal blood loss. The postoperative period was uneventful. The patient was discharged on the 5th day in a satisfactory condition. The parameters of platelet level have reached the reference values $\left(356 \times 10^{9} / 1\right)$.

Conclusion. Preoperative 3D modelling permits the surgeon to make pre-operative planning and provides him with important information on individual topographic and anatomic features in forthcoming operation sites. 
The information about the individual characteristics of the splenic vascularization and pancreatic topography in its gate lets to allocate and ligate vessels precisely, that improves the quality of hemostasis and also reduces the probability of the pancreatic injury. Preoperative visualization of accessory spleens increases the radicalism of the surgery.

Keywords: splenectomy, thrombocytopenia, computer tomography, 3D modelling, hemostasis, vascularization

Novosti Khirurgii. 2017 Mar-Apr; Vol 25 (2): 177-182

Preoperative 3D Modeling Splenectomy in Patients with Primary Immune Thrombocytopenia

S.E. Katorkin, A.V. Kolsanov, S.A. Bystrov, S.S. Chaplygin, P.M. Zelter, R.M. Nazarov

\section{Introduction}

A splenectomy is indicated for the management of patients with idiopathic thrombocytopenic purpura in the case of inability of conservative therapy; $80 \%$ of patients recover without special treatment. Splenectomy is so-called "second line" of ITP therapy in case of resistance to corticosteroids. [1]. Nowadays laparoscopic splenectomy is emerging 'gold standard' treatment, characterized by better treatment outcomes in contrast to congentional laparotomy [2].

To improve the treatment outcomes the embolization of splenic vessels is sometimes used which enable to reduce the risk of intraoperative bleeding [3]. However, according to various authors' reports the number of conversions to laparotomy, especially at the mastering stages reaches $15-25 \%$. The intra-abdominal bleeding from unligated vessels not visualized within the operation is a major cause for conversion to laparotomy; the development of new surgical approaches have been required [4].

Prediction of the splenectomy efficacy and selection of the optimal surgical access based on topographic and anatomical features of the surgical site is certainly of great importance.Technology of three-dimensional (3D) medical images of computed tomographic (CT) data has become widely used in the diagnosis within recent decade $[5,6]$.

A new trend of today's surgery is considered to be a preoperative modeling of the surgery site [7]. Systems for design of 3D modeling with possible intraoperative navigation are actively being studied at present, particular, in thermal ablation of metastases to the liver in colorectal cancer [8], and also widely used in creation of surgical virtual simulators [9]. In the Center of breakthrough research of Samara State Medical University, "Information Technologies in Medicine," the group of specialists, including surgeons, radiologists and programmers conducts the collaborative development and implementation of software package "Autoplan" giving the ability to plan surgical intervention with a possibility of semi-automatic segmentation. At the same time the parenchymal organs, arteries and veins are separately segmented in the corresponding phases of contrasting.

Systems giving the ability to plan surgical intervention combines the medical equipment, PACS system (picture archiving and communication system) available onsite advanced image-viewing workstations that can guide physicians; the ability to view images from various workstations via the network including the navigation enabling physicians to create the accurate and realistic models from stereo cameras, and to use computers as well as mobile computing devices directly in the operating room. Samara State Medical University has accumulated positive experience of using preoperative 3D modeling; particularly it concerns the operations for volumetric liver formations [10].

Objectives. To study the efficacy of the method of volume visualization in surgery (preoperative 3D modeling) based on captured CT scan digital data in performing laparoscopic splenectomy for the primary immune thrombocytopenia.

\section{Results}

The experience of using preoperative colored $3 \mathrm{D}$ model of the operation in the surgery on the spleen is analyzed in this clinical observation. A 55 -year old woman remaining thrombocytopenic due to ITP for 10 years.

For a long time she has been treated conservatively but ineffectually by hematologists in the Clinics of Samara State Medical University. The diagnosis of the primary immune thrombocytopenia was verified by hematologists according to the survey protocol of the patients with thrombocytopenia [1]. Anamnestic platelet count reduced up to $10 \times 10^{9} / 1$, constant nasal and gingival bleeding and subcutaneous bleeding occured. Due to the permanent histories of periodontal disease the patient has lost most of the teeth. The patient took $60 \mathrm{mg}$ of prednisone daily for the recent year. Long-term anamnesis, failure of conservative therapy, low platelet count despite high doses of glucocorticoids, the threat of intracranial hemorrhage were considered to be the indication for surgical treatment - splenectomy.

On admission to a surgical department of the Clinic of hospital surgery of Samara State Medical University, the marked clinical signs of the Itsenko-Cushing's syndrome were registered in the patient, the platelet count was $36 \times 10^{9} / 1$, numerous bruises were visualized on the body. Objectively: 

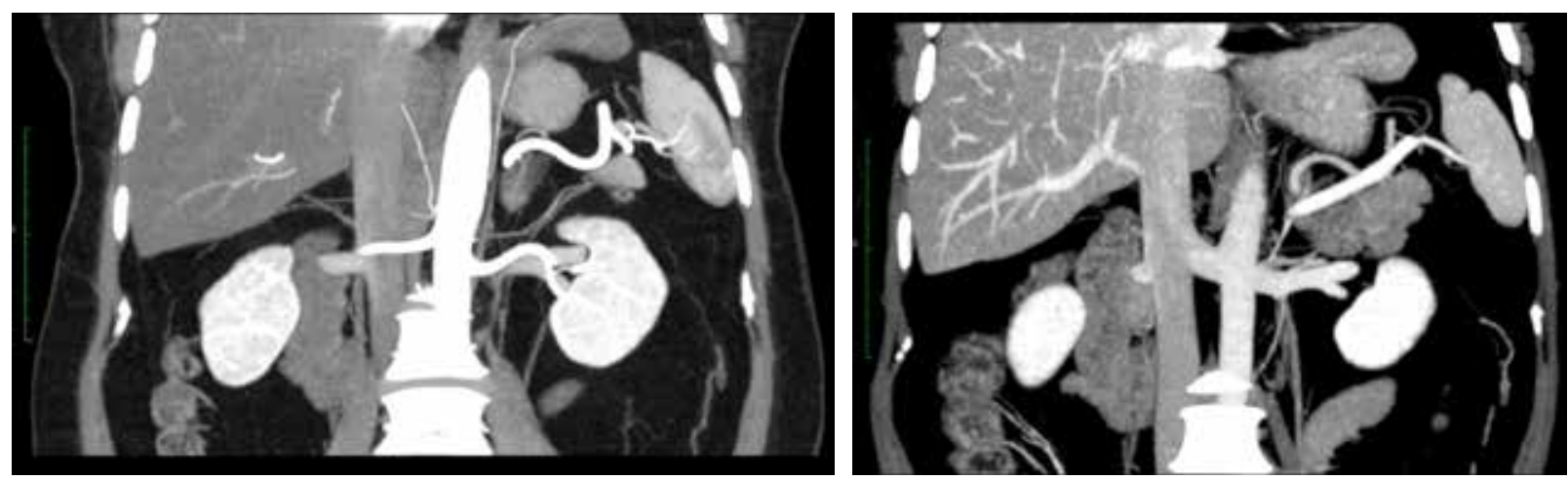

Fig. 1. Computed tomography in the coronal plane. Arterial Fig. 2. Computed tomography in the coronal plane. phase in the maximal intensity projections: $10 \mathrm{~mm}$ thickness Venous phase in the maximal intensity projections: $10 \mathrm{~mm}$ thickness

general state of a patient was closer to satisfactory, numerous subcutaneous bleedings on the skin of limbs, and some fat deposits and stretch marks typical for corticosteroids overdose were observed on the body and face. A persistent hypertension (180 and $100 \mathrm{mmHg}$ ), tachycardia up to 110 beats per minute were noted. Ultrasound examination of the abdominal organs showed the signs of chronic cholecystitis and chronic pancreatitis. The spleen had normal dimensions $95 \times 45 \mathrm{~mm}$; its area was $38,8 \mathrm{~mm}^{2}$. Changes of echostructure and focal splenic lesions were not revealed. The fibrogastroduodenoscopy showed some signs of an erosive hemorrhagic gastritis. A postoperative multislice computed tomography of the abdominal organs (tomograph TOSHIBA (Aquilion 32 (Japan) with a bolus of contrast medium) was carried out, $100 \mathrm{ml}$ of low-osmolar iodinated contrast media via the elbow catheter was introduced (Fig. 1, 2).

In the "Autoplan" system the color CT-based 3D model of the upcoming surgery was designed (Fig. 3, 4).

Fig. 3. Polygon 3D-model. View from above. Bones, spleen, pancreas, arteries and veins are marked with different colors.

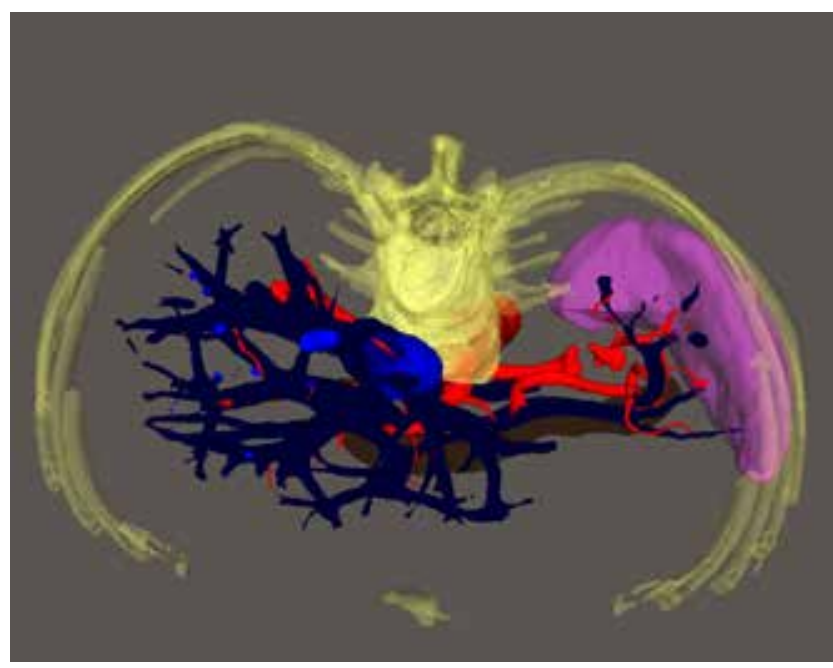

On the basis of this model the possibility of performing standard laparoscopic hybrid splenectomy was predicted. According to the designed model no vascular abnormalities, accessory vessels or accessory spleens, peritoneal process, close location of the pancreatic tail to splenic hilum have been detected. The patient underwent the hand-assisted laparoscopic hybrid splenectomy using Hand Port. Surgery was conducted under combined endotracheal anesthesia; the patients were positioned in left lateral position with a roller.

During the surgery three ports were installed: 1 - Hand Port in the left subcostal area parallel and $3 \mathrm{~cm}$ below the left costal arch margin; Port $2(10 \mathrm{~mm})$ for insufflation and video system with a visual angle of $30^{\circ}$ in the left mesogastric area 3 $\mathrm{cm}$ above the navel; Port $3(15 \mathrm{~mm})$ in the left side to introduce the working tools - harmonic shears, clipper and suturing device.

Mobilization of the spleen was performed by means of ultrasonic shears from the lower to the upper pole along the lateral spleen surface. Some

Fig. 4. Polygon 3D-model. Front view. Bones, spleen, pancreas, arteries and veins are marked with different colors.

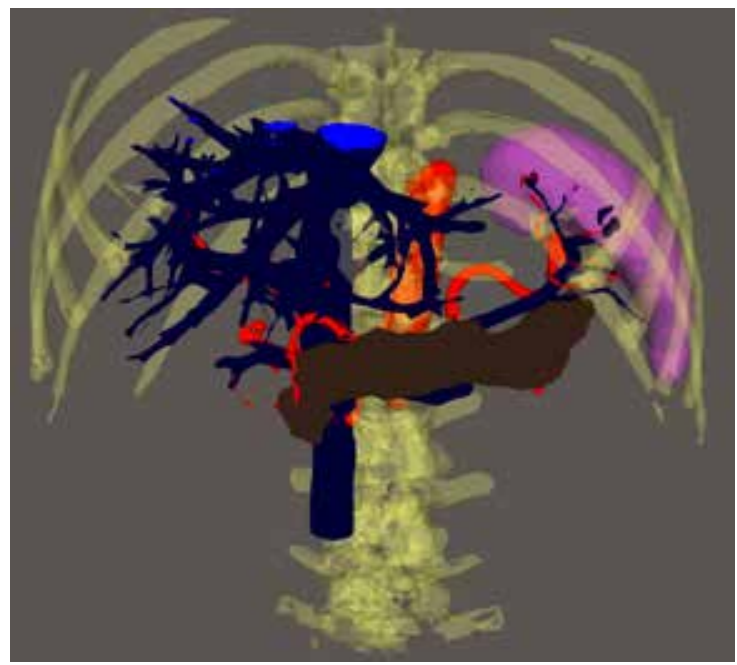


vessels were clipped and crossed. The pedicle of the spleen was sewed and cut off with the endoscopic sewing-cutting device with a blue cassette (suture length $-45 \mathrm{~mm}$, staples height $-3.5 \mathrm{~mm}$ ). The spleen was removed from the abdominal cavity through HandPort. Revision of the spleen bed for accessory spleens was obligatory. Intraoperative blood loss was less than $50 \mathrm{ml}$. The patient was installed the control drainage of the splenic bed through the lateral port. The duration of surgery was 75 minutes.

This postoperative period was significantly different from those where patients were operated on via the laparotomy access. In the early incisional period after the laparoscopic hybrid splenectomy a minimal pain syndrome was registered, and administration of narcotic analgesics was not required. By the end of the first day the patient was activated. The intestinal function was restored in a day. Abdominal drainage was removed on the $3^{\text {rd }}$ day. Totally about $100 \mathrm{ml}$ of serous-hemorrhagic discharge was secreted via the drainage. The postoperative period was uneventful. The patient was discharged on the $5^{\text {th }}$ day with normal platelet count $\left(356 \times 10^{9} / 1\right)$. Doses of Prednisolone were reduced according to the scheme until treatment discontinuation. The patient was assessed one month after the surgery. There were no complaints. The satisfactory state was registered. Platelet count was $325 \times 10^{9} /$ l. Ability to work was fully restored.

\section{Discussion}

Spleen surgery is one of the least explored sections of the abdominal surgery. The recent studies concerning the function of this organ have shown its critical role in supporting the body's normal immune and hematopoietic status. Nowadays in case of the spleen pathology the organ-saving operations have replaced the conventional splenectomy. However, in hematological patients splenectomy must be done and all accessory spleens be sought and removed. The modern development of medicine involves the use of high-tech diagnostic equipment and the application of new methods in clinical surgery. A laparoscopic splenectomy may well be considered the surgical treatment of choice in hematology.

But is it always possible to perform it and where is the limit of endovideolaparoscopic technologies? When should the preference be given to a conventional laparotomic operative technique?

Undoubtedly, common sense and safety principle should not yield to the desire of the surgeon to perform the operation laparoscopically by all means. Preoperative knowledge of topographic and anatomical features of the operative site by the surgeon is, without any doubt, of great importance and able affect the choice of splenectomy method.

Surgical Department of the Clinic of Hospital Surgery of Samara State Medical University has experience of performing over 500 splenectomies in patients with hematological diseases; however, surgical selection criteria for the operation approach were mainly determined on the basis of surgeon's personal preference or empirical experience. Currently, objectivisation and standardization are needed in the choice of the operative treatment method in hematological patients. Indications and contraindications to the laparoscopic technique are relative.

The authors assume that the preoperative color 3D modeling may become one of the objective selection criteria of the splenectomy. For example, in the case of revealing of large sizes of the spleen, multiple accessory spleens, atypical vascularization of an organ, abnormal anatomic relationships, a conventional surgery likely confers a more expedient. Conversely, minimally invasive surgery is reliably performed in the uncomplicated topographic anatomical picture. Multislice computed tomography with the bolus contrasting is a standard tool for the diagnosis of the spleen diseases. The method permits to differentiate benign and malignant tumors, to determine their vascularization and topographic-anatomic relationships with various vascular structures and the pancreas.

According to CT information and the analysis of data in the system "Autoplan" of the color 3D model the patient had the main type of vascularization of the spleen.

Splenic vein was formed from four venous trunks. Splenic artery was also divided into four smaller branches. The tail of the pancreas did not reach the splenic hilum $(1.5 \mathrm{~cm})$. No accessory spleens and peritoneal process around it was found.

The obtained information of those reconstruction models were totally confirmed within the surgery and thus allowed performing a hybrid laparoscopic splenectomy precisely with minimal blood loss. Knowledge of the pancreatic tail topography helped to avoid intraoperative injury with possible development of the postoperative pancreatitis. In the domestic literature the issue of $3 \mathrm{D}$ modeling is presented fragmentary. The monograph "Virtual surgical simulation on the basis of the computer tomography data" had some limitations due to the equipment defects at the stage of the research implementation: single-slice spiral computed tomography was used; to get an accurate arterial and venous phases of contrasting was impossible due to the low speed of the tube rotation [11].

The presented clinical observation is our first experience on the spleen surgery and allows making 
only preliminary optimistic conclusions. Undoubtedly, this line of research is promising; it requires further study, multidisciplinary approach and active implementation.

\section{Conclusion}

Due to preoperative 3D modeling the surgeons enable to evaluate their preoperative planning decisions and understood better the surgical operations, taking into account the knowledge about individual topographic and anatomical features of the surgery site.

Knowledge of the individual characteristics of the splenic vascularization and pancreatic topography permits to allocate precisely and to ligate the vessels, to improve hemostasis and to reduce the probability of pancreatic injury. Preoperative visualization of accessory spleens increases the radicalism of the operation.

The work was performed in accordance with the Research Plan of FSBEE HE "Samara State Medical University." Financial support from the companies-manufacturers of drugs was not received by the authors.

\section{ЛИТЕРАТУРА}

1. Меликян АЛ, Пустовая ЕН, Цветаева НВ, Савченко ВГ. Клинические рекомендации по диагностике и лечению идиопатической тромбоцитопенической пурпуры (первичной иммунной тромбоцитопении) у взрослых. Москва, РФ; 2014. 42 с. 2. Воробей АВ, Лурье ВН, Александров СВ, Римжа ЕА, Рылюк АФ, Швед ИА, и др. Место лапароскопической спленэктомии в хирургической гематологии. Новости Хирургии. 2007;15(2):52-64.

3. Корытцев ВК, Быстров СА, Сухоруков ВВ, Толкачев ЮС. Гибридная операция при идиопатической тромбоцитопенической пурпуре. Хирургия Журн им НИ Пирогова. 2015;(9):83-85.

4. Гржимоловский А.В., Карагюлян С.Р., Данишян К.И. Лапароскопическая спленэктомия в гематологии. Эндоскоп Хирургия. 2003;9(4):3-14.

5. Blackmore CC, Mecklenburg RS, Kaplan GS. Effectiveness of clinical decision support in controlling inappropriate imaging. J Am Coll Radiol. 2011 Jan;8(1):19-25. doi: 10.1016/j.jacr.2010.07.009.

6. Brouwer OR, Buckle T, Bunschoten A, Kuil J, Vahrmeijer AL, Wendler $\mathrm{T}$, et al. Image navigation as a means to expand the boundaries of fluorescence-guided surgery. Phys Med Biol. 2012 May 21;57(10):312336. doi: 10.1088/0031-9155/57/10/3123.

7. Kwon YW, Powell KA, Yum JK, Brems JJ, Iannotti JP. Use of three-dimensional computed tomography for the analysis of the glenoid anatomy. J Shoulder Elbow Surg. 2005 Jan-Feb;14(1):85-90.

8. Banz VM, Baechtold M, Weber S, Peterhans M, Inderbitzin D, Candinas D. Computer planned, image-guided combined resection and ablation for bilobar colorectal liver metastases. World J Gastroenterol. 2014 Oct 28;20(40):14992-96. doi: 10.3748/wjg.v20. i40.14992.

9. Volonté F, Pugin F, Bucher P, Sugimoto M, Ratib O, Morel P. Augmented reality and image overlay navigation with OsiriX in laparoscopic and robotic surgery: not only a matter of fashion. J Hepatobiliary Pancreat Sci. 2011 Jul;18(4):506-9. doi: 10.1007/s00534-0110385-6.

10. Колсанов АВ, Зельтер ПМ, Манукян АА, Чаплыгин СС., Колесник ИВ. Применение системы по предоперационному моделированию на основе данных компьютерной томографии у больного эхинококкозом печени. REJR. 2016;6(2):111-14. doi:10.21569/2222-7415-2016-6-2-111-114.

11. Федоров ВД, Кармазановский ГГ, Гузеева ЕБ, Цвиркун ВВ. Виртуальное хирургическое моделирование на основе данных компьютерной томографии. Москва, РФ: Видар-М; 2003. 184 с.

\section{REFERENCES}

1. Melikian AL, Pustovaia EN, Tsvetaeva NV, Savchenko VG. Klinicheskie rekomendatsii po diagnostike i lecheniiu idiopaticheskoi trombotsitopenicheskoi purpury (pervichnoi immunnoi trombotsitopenii) u vZroslykh [Clinical guidelines for the diagnosis and treatment of idiopathic thrombocytopenic purpura (primary immune thrombocytopenia) in adults]. Moscow, RF; 2014. $42 \mathrm{p}$.

2. Vorobei AV, Lur'e VN, Aleksandrov SV, Rimzha EA, RyliukAF, Shved IA, i dr. Mesto laparoskopicheskoi splenektomii v khirurgicheskoi gematologii [Place of laparoscopic splenectomy in surgical hematology]. Novosti Khirurgii. 2007;15(2):52-64.

3. Koryttsev VK, Bystrov SA, Sukhorukov VV, Tolkachev IuS. Gibridnaia operatsiia pri idiopaticheskoi trombotsitopenicheskoi purpure [Hybrid operation in idiopathic thrombocytopenic purpura]. Khirurgiia Zhurn im NI Pirogova. 2015;(9):83-85.

4. Grzhimolovskii A.V., Karagiulian S.R., Danishian K.I. Laparoskopicheskaia splenektomiia v gematologii [Laparoscopic splenectomy in hematology]. Endoskop Khirurgiia. 2003;9(4):3-14.

5. Blackmore CC, Mecklenburg RS, Kaplan GS. Effectiveness of clinical decision support in controlling inappropriate imaging. J Am Coll Radiol. 2011 Jan;8(1):19-25. doi: 10.1016/j.jacr.2010.07.009.

6. Brouwer OR, Buckle T, Bunschoten A, Kuil J, Vahrmeijer AL, Wendler T, et al. Image navigation as a means to expand the boundaries of fluorescence-guided surgery. Phys Med Biol. 2012 May 21;57(10):312336. doi: 10.1088/0031-9155/57/10/3123.

7. Kwon YW, Powell KA, Yum JK, Brems JJ, Iannotti JP. Use of three-dimensional computed tomography for the analysis of the glenoid anatomy. $J$ Shoulder Elbow Surg. 2005 Jan-Feb;14(1):85-90.

8. Banz VM, Baechtold M, Weber S, Peterhans M, Inderbitzin D, Candinas D. Computer planned, image-guided combined resection and ablation for bilobar colorectal liver metastases. World J Gastroenterol. 2014 Oct 28;20(40):14992-96. doi: 10.3748/wjg.v20. i40.14992.

9. Volonté F, Pugin F, Bucher P, Sugimoto M, Ratib $\mathrm{O}$, Morel P. Augmented reality and image overlay navigation with OsiriX in laparoscopic and robotic surgery: not only a matter of fashion. J Hepatobiliary Pancreat Sci. 2011 Jul;18(4):506-9. doi: 10.1007/s00534-0110385-6.

10. Kolsanov AV, Zel'ter PM, Manukian AA, Chap- 
lygin SS., Kolesnik IV. Primenenie sistemy po predoperatsionnomu modelirovaniiu na osnove dannykh komp'iuternoi tomografii u bol'nogo ekhinokokkozom pecheni [The use of preoperative simulation system based on the data of computer tomography in a patient with liver echinococcosis]. REJR. 2016;6(2):111-

\section{Адрес для корреспонденции}

443079, Российская Федерация,

г. Самара, пр. Карла Маркса, д. 165 «б»,

Клиники Самарского государственного

медицинского университета,

кафедра и клиника госпитальной хирургии, тел. раб.: 810846 276-77-89,

e-mail: katorkinse@mail.ru,

Каторкин Сергей Евгеньевич

\section{Сведения об авторах}

Каторкин С.Е., к.м.н., доцент, заведующий кафедрой и клиникой госпитальной хирургии ФГБОУ ВО «Самарский государственный медицинский университет».

Колсанов А.В., д.м.н., профессор, заведующий кафедрой оперативной хирургии и клинической анатомии с курсом инновационных технологий ФГБОУ ВО «Самарский государственный медицинский университет», директор Института инновационного развития, руководитель Центра прорывных исследований «Информационные технологии в медицине». Быстров С.А., к.м.н., доцент, заведующий хирургическим отделением клиники госпитальной хирургии ФГБОУ ВО «Самарский государственный медицинский университет».

Чаплыгин С.С., к.м.н., доцент кафедры оперативной хирургии и клинической анатомии с курсом инновационных технологий ФГБОУ ВО «Самарский государственный медицинский университет».

Зельтер П.М., к.м.н., ассистент кафедры лучевой диагностики и лучевой терапии с курсом медицинской информатики ФГБОУ ВО «Самарский государственный медицинский университет».

Назаров Р.М., врач-хирург хирургического отделения клиники госпитальной хирургии ФГБОУ ВО «Самарский государственный медицинский университет».

\section{Информация о статье}

Поступила 3 октября 2016 г.

Принята в печать 12 декабря 2016 г. Доступна на сайте 28 марта 2017 г.
14. doi:10.21569/2222-7415-2016-6-2-111-114.

11. Fedorov VD, Karmazanovskii GG, Guzeeva EB, Tsvirkun VV. Virtual'noe khirurgicheskoe modelirovanie na osnove dannykh komp'iuternoi tomografii [The virtual surgical simulation on the basis of computer tomography data]. Moscow, RF: Vidar-M; 2003. 184 p.

\section{Address for correspondence}

443079, Russian Federation, Samara, Karl Marx pr., 165, «b»,

Clinics of Samara State Medical University, department and clinic of hospital surgery.

Tel.: 810846 276-77-89

e-mail: katorkinse@mail.ru

Sergey E.Katorkin

\section{Information about the authors}

Katorkin S.E. PhD, Ass. Professor, Head of department and clinic of hospital surgery, FSBEE HE «Samara State Medical University».

Kolsanov A.V. MD, Professor, Head of operative surgery and clinical anatomy department with the course of innovative technologies, FSBEE HE «Samara State Medical University», Director of Institute of innovative Development, Head of the Center of breakthrough researches «Information Technologies in Medicine.» Bystrov S.A., PhD, Ass. Professor, Head of clinic of hospital surgery, FSBEE HE «Samara State Medical University».

Chaplygin S.S. PhD, Ass. Professor of operative surgery and clinical anatomy department with the course of innovative technologies, FSBEE HE «Samara State Medical University».

Zelter P.M. PhD, Assistant of department radiology fnd radiotherapy with the course of medical information, FSBEE HE «Samara State Medical University».

Nazarov P.M. Surgeon of surgical department of the hospital surgery clinic, FSBEE HE «Samara State Medical University».

\section{Article history}

Recieved 3 October 2016

Accepted 12 December 2016

Available online 28 March 2017 